\title{
Complex estimation of the effect of long-term radioactive contamination on soil mezofauna after Chernobyl accident
}

\author{
S. Maksimova \\ Institute of Zoology, National Academy of Sciences of Belarus, \\ Akademicheskaya 27, 220072 Minsk, Belarus
}

\begin{abstract}
We have carried out the pedobiological investigation in the forest (broad-leaved and pine) biogeocenoses of the zone of radioactive contamination, Belarus. Considerable differences were found in the number of species between biogeocenoses with different levets of contamination. Higher radionuclide content was found to result in suppression of soil mezofauna, which manifested by a decrease in density and zoomass. We bave established the sings of pathological condition of invertebrate hemolymph subject to radioactive contamination. All the facts indicate that soil mezofauna in biogeocenoses exposed to radiation for a long time impact clearly noticeable suppression.
\end{abstract}

\section{INTRODUCTION}

The Chernobyl nuclear accident in 1986 resulted in contamination of vast areas not only in the former USSR, but also in many European countries. Belarus, which received above $70 \%$ of the fallout, was affected most of all.

The most serious impact on the natural environment was within a radius of $30 \mathrm{~km}$ of the reactor, where the level of contamination was very high and diversity of radionuclides was most evident.

Natural biogeocenoses, were exposed to acute radiation that gradually became chronic due to long-lived radionuclides. After the Chernobyl accident forest ecosystems were contaminated with radionuclides with analogy to the other natural landscapes. Forest ecosystems are known to be extremely sensitive to ionizing radiation. Forests can retain, redistribute and deposit radionuclides. However, they are not able to neutralize the radioactivity absorbed. Soil organisms may play an important role in the transfer of radionuclides through the radionuclide-polluted ecosystem. They comprise $90-95 \%$ of animal species of zoocenoces and $90 \%$ of total zoomass [1]. In studying the consequences of the Chernobyl disaster, the problem of radiomonitoring of the environment now includes the soil biocenose. To evaluate its role we have carried out a pedobiological investigation in the various forest ecosysterns over the Republic of Belarus after Chernobyl nuclear disaster.

The main goal of this study was to investigate the effect of a high radioactive background on the soil animals in different forests. The objectives were [1] to investigate the main trends in the changes of soil invertebrate communities subject to radioactive contamination; [2] to reveal the character and degree of the radiocontamination effect on the functional groups; [3] to characterize the state of invertebrate hemolymph under radiological pressure.

Such studies have never been carried out previously in Belarus, though in view of the actual situation caused by the Chernobyl nuclear accident they are very topical.

\section{MATERIALS AND METHODS}

The materials were collected in Gomel region, at the site the of Polessky Radio-Ecological Reserve which currently exhibits a contamination level of up to $1500 \mathrm{kBq} \mathrm{m}^{-2}$.

Soil samples were collected at 0 to $25 \mathrm{~cm}$ depth. Samples were taken in locations, which had received considerable radionuclide contaminations. The gamma-radiation at the soil surface was measured with SRP 68-01 and DRG 01 T radiometers. As a control, similar biogeocenoses within the Pripyat 
Hydrological Landscape Reserve (now National Park "Pripyatski"), located $150 \mathrm{~km}$ to the west of the study area, were chosen, where the contamination level was close to the natural background.

Soil invertebrates were sampled each year (between mid-April to October) from 1986 to 1999, using the methods conventional in pedobiological investigations (the soil samples and pit-full traps) at reference forest sites (Republic of Belanus). These sites differed in contamination by the composition of fall-out, the forms of radionuclides content in soils, their intake into trophic chains and accumulation in animal and plant organisms. Within the same forest biogeocenose type (broad-leaved and pine) study sites were chosen:

1) The weak radioactive contamination site $(0,2-0,27 \mathrm{mr} / \mathrm{hr})-\mathrm{v}$. Babchin

2) The strong radioactive contamination site $(3,7-6,4 \mathrm{mr} / \mathrm{hr})-\mathrm{v}$. Kulazhin

\section{RESULTS AND DISCUSSION}

The gamma-survey of surface soil, where soil invertebrates are living, shows that the contamination of soil cover is inhomogeneous in forests. A wide range of gamma-activity and radionuclide content both, in soil and in litter, and from seasons to years, was observed in radioactively contaminated forest biogeocenoses. The radionuclides from the Chernobyl outburst are concentrated up to $90-95 \%$ in the upper part of the soil profile (layer of $0-10 \mathrm{~cm}$ ). The radionuclide spectrum appeared to be represented by 14 elements (alpha, beta and gamma-sources). Large-scale fallout is also spatially heterogeneous, i.e. territorial distribution of nuclides such as ${ }^{93} \mathrm{Zr},{ }^{141} \mathrm{Ce},{ }^{144} \mathrm{Ce},{ }^{134} \mathrm{Cs}$ and ${ }^{137} \mathrm{Cs}$ varied widely. Forest litter was still an accumulator of radionuclides and this greatly influences the migration in forest soil. Currently, the main dose-forming elements are ${ }^{137} \mathrm{Cs}$ and ${ }^{90} \mathrm{Sr}$.

Investigations in forests of the Chernobyl's $30 \mathrm{~km}$ zone have shown a decrease in the exposure dose. In 10 years, the irradiation intensity has decreased five times, with the portion of beta-radiation with respect to total having decreased twice. Within the forest, the spots of higher radioactivity are limited to openings. The highest specific gamma-activities, as well as maximum percentage and amount of radioisotopes, were recorded at the forest edges exposed to winds. This pattern may be attributed to peculiarities of radionuclides fall-out at the edges as compared with the forest bulk, which is characteristic of both pine and broad-leaved forests. The heterogeneity in irradiation dose distribution decreases with distance from the destroyed reactor and from the axis of the radioactive trace.

Studying zoocenotic characteristics such as population density, trophic structure and species composition of soil invertebrates inhabiting forest biogeocenoses aims at identifying and characterizing the soil invertebrate communities most sensitive to radioactive contamination. The changes in the invertebrate communities were based on the following parameters: dynamic density and species composition, zoomass, trophic structure, and radionuclide accumulation and hemolymph composition.

\subsection{Changes in density and species composition}

Within the first four years after the Chemobyl nuclear accident invertebrates experienced substantial changes as exhibited by decreases in dynamic density and zoomass, disturbance of the trophic structure and decrease of viability of the populations. Large taxonomic soil mezofauna groups were not found in the contaminated biogeocenoses. Radioactive contamination affects not only permanent soil inhabitants but also actively migrating invertebrates. The dynamic density of saprophages, phytophages and zoophages was found to decrease due to radioactive contamination. This decrease reduces the biological activity of the soil and indicates serious disturbances in the soil invertebrate communities. Overall, a sharp decrease of dynamic density of soil invertebrates in the zone of strong radioactive contamination was found (Figure 1). 


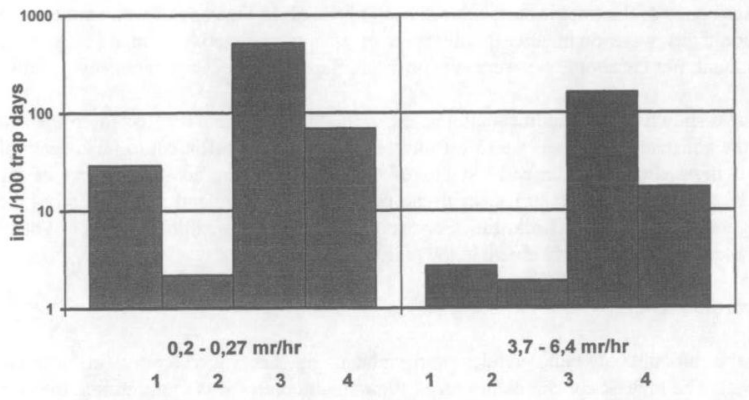

Figure 1: The dynamic density of several groups of soil mezofauna in the biogeocenoses with weak and strong radioactive contamination ( 1 - Arachnida, 2 - Myriapoda, 3 - Fornicidae, 4 - Coleoptera)

After 5- 6 years marked differences between soil invertebrates populations in contaminated and control areas were found, with species diversity in contaminated soils five times lower. During last years of this investigation, the animal biodiversity and community structure was observed to slowly return to the initial parameters. Secondary changes and side effects were registered for phytophages and saprophages. This study showed that the species composition was poorer under increased level of radioactive contamination. For example, 3 species of Lumbricidae (earthworms) have been identified in the contaminated site. There are: Octalasium lacteum (Oerley, 1885); Lumbricus rubellus (Hoffmeister, 1843); Dendrobaena octaedra (Savigny, 1826). In the control areas, in contrast, 6 species were found. Similarly, 12 Diplopoda (millipedes) species were collected in the radiocontaminated forest biogeocenoses, (i.e. almost $50 \%$ of the total 23 diplopod species presently known from Belarus) areas, whereas 20 species were recorded in control sites.

\subsection{Changes of zoomass}

Zoomass is not an indicator of changed conditions as good as density since individual weight in the same species can vary. Despite this fact, invertebrate zoomass diminished in all the contaminated biogeocenoses. The percentage of zoomass decrease in all communities is larger than that of density [2]. The decrease may be attributed to the disappearance of families or species, which dominated in the control biogeocenoses.

\subsection{Changes of the trophic structure}

The dynamics of the trophic structure, whose changes are indicative of drastic disturbance in the soil invertebrate communities, is an even better indication than density and zoomass. The trophic groups have been characterized based on density and zoomass. 
Overall, the disturbance of the trophic structure has been revealed. In the zone of weak radioactive contamination, the zoophages were dominant. In the zone of strong radioactive contamination, the phytophages were dominant, but the zoophages were subdominant. Saprophages disappeared completely [3].

These results have shown that the radiocontamination in the $30 \mathrm{~km}$ zone has affected on the soil fauna, particularly on the constant dwellers of the forest litter. The doses were sufficient to yield death of eggs and of nearly all invertebrates at the early stages of development. The adverse effects of the contamination should be associated with disturbances in the process of breeding and regeneration of the population and their age-sex composition (Kulazhin). For example, earthworms exhibited a lot of young individuals at the control site but were nearly absent at the radiocontaminated site.

\subsection{Accumulation of radionuclides}

We have estimated the amount of radionuclides accumulated by the invertebrates in different biogeocenoses (Figure 2). The highest contamination level in the invertebrates was found during the year corresponding to the Chemobyl nuclear accident. However, the ratio of gamma- to beta-sources was varying among different invertebrate groups. Saprophages, which are a final link in the trophic chains, accumulated radionuclides most. Then, phytophages followed, zoophages being the last. In Diplopoda, Oniscoidea (wood-lices), Gastropoda (shelled mollusks) and Formicidae (ants) the portion of beta radionuclides was higher, the proportion being lower in Geotrupes and slugs, whereas in Lumbricidae beta and gamma activities were nearly identical. Gamma-activity of invertebrates was found to decrease with time (Figure 2). Similar changes were observed also for gamma-radionuclides in the litter and in the soil, but the contents of gamma-sources in the litter being higher. It has been found that from 1986 to 1990 the radionuclide contents in soil invertebrates had decreased several times, then the decrease was slower. Meanwhile, the radionuclide amount in the soil biotopes studied became four times lower during the same period. Some trends in radionuclide accumulation by animals associated with their ecological characteristics have also been found. For example: the radionuclide level in insects depends on their way of life and feeding type. The highest concentration is characteristic of insect groups that are in contact with soil and saprophages.

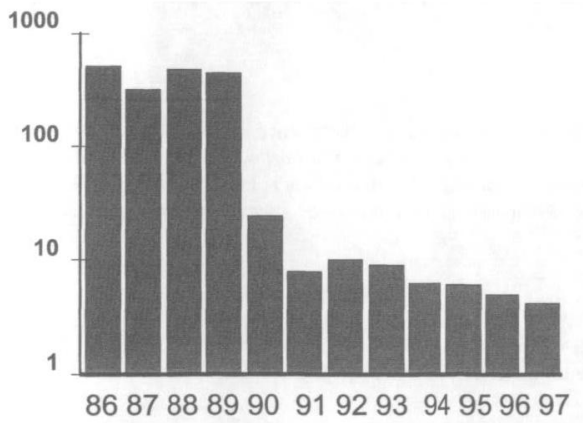

Figure 2: Dynamics of radionuclide accumulation by soil mezofauna $(\mathrm{kBq} / \mathrm{kg}$, wet weight) 


\subsection{Changes in hemolymph}

Studies of structural changes in animal tissues, blood in particular, which can serve as an additional objective indicator, are of special importance for estimating the state of exposed organisms. Hemolymph performs vital functions in invertebrates, e.g., metabolic, homeostatic and protective. Its cellular composition is a reliable indicator of population viability. In the hemolymph of both normal and irradiation-exposed insects, five bemocyte types were revealed: proleucocytes, macronucleocytes, micronucleocytes, oenocytoides and phagocytes [4]. The proportion of hemocytes varies with the physiological conditions.

The results obtained indicate statistically significant increases in the total number of dead cells in hemolymph of exposed invertebrates (from 13 up to 76 per 100 cells) compared to control (only $2-3$ ). It has been revealed that at the early development stage of radiation lesion the amount of hemocytes, involved in phagocytosis reactions, primarily, of active phagocytes, increases in bemolymph. Subsequently, the number of dead cells rises and the highest number of phagocytes coincides with a sharp decrease in micronucleocytes and a substantial increase of dead cells. The greatest changes in hemolymph correspond to the highest radiocontamination level (Figure 3). The morphological changes are as follows: lyses, fission shift of the nucleus to the cell periphery, disturbance of circular shape in some cells, elongation, cytoplasm budding and vacuolization.

It has been shown that the ratio between hemocytes is an extremely sensitive indicator of radioactive contamination.

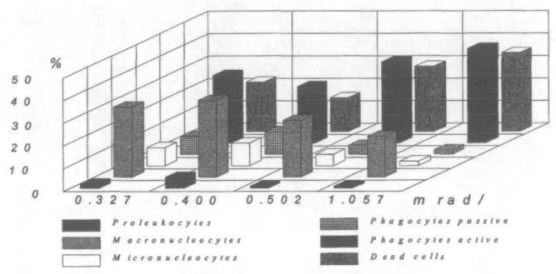

Figure 3: Cellular composition of hemolymph, in percentage of the various hemocytes types, as a function of radiation dose rate 


\section{CONCLUSION}

Thus, our studies allowed us to estimate correctly the changes induced by radioactive contamination caused by Chemobyl nuclear accident at the level of soil invertebrate communities and to reveal the pattern of their disturbance under constant radiological pressure. In the contaminated forest biogeocenoses higher radionuclide content was found to result in substantial, well registered, suppression of soil mezofauna, which is manifested by a decrease of dynamic density, zoomass and disturbance of the trophic structure. Considerable differences in the species number were found between biogeocenoses with different levels of contamination. Sharp decrease of dynamic density of soil invertebrates in the zone of strong radioactive contamination was found. It is concluded from these results that the hematological characteristics can serve as convenient bioindicator of the radioactive contamination.

\section{References}

[1] Krivolutzky D.A., Tichomirova A.L., Turchaninova V.A., Pedobiologia 12 (1972) 347 - 380.

[2] Maksimova S.L., Pakistan, J.Zool. 28 (1996) $277-281$.

[3] Maksimova S.L., The dynamics of radioactive contamination of soil fauna, Materials of International conference devoted to 100-years of N.V. Timopheev-Resovsky, Minsk, $17-18$ October 2000, A. Milutin and I. Mosse, Eds. (Trioletta, Minsk, 2000) pp. 13- 15 (in Russian).

[4] Sirotina M.I., Dokl. VASKhNIL. 4 (1965) 22-28 (in Russian). 